\title{
ANALÝZA SPOTŘEBY ENERGIÍ PŘI VÝSTAVBĚ BYTOVÝCH DOMŮ
}

\author{
ANALYSIS OF ENERGY CONSUMPTION DURING \\ THE CONSTRUCTION OF APARTEMENT BUILDINGS
}

\author{
Jana Lukášková, ${ }^{*}$
}

*xsprazakovaj@vutbr.cz

${ }^{1}$ VUT v Brně, Fakulta stavební, Veveři 95, 60200 Brno

\begin{abstract}
Abstrakt
Současná legislativa se zaměřuje na minimalizaci množství spotřebované energie při uživání stavby, není však řešena energie vynaložená při výstavbě objektu. V porovnání s celým životním cyklem stavby tato energie tvoří malý podíl, ale i v této etapě výstavby lze shledat úspory. S ohledem na aktuální rychlý růst cen energií je každá úspora energie znatelná. Předmětem článku je problematika negativního dopadu nedodržení harmonogramu postupu prací či jeho neoptimální návrh na navýšení množství vydané energie při výstavbě. Cúlem výzkumu je kvantifikace spotřeby jednotlivých druhů vložené energie při výstavbě a stanovení měrné spotřeby pro účely následného porovnání a zhodnocení. Je provedena analýza energetických výdejů, stanovení kritických činností vyžadujících významné množství energie a komparace pěti případů výstavby bytových domů.
\end{abstract}

\section{Klíčová slova}

Harmonogram postupu prací, spotřeba energie, zimní opatření, vytápění

\begin{abstract}
The current legislation focuses on minimizing the amount of energy consumed during the use of the building, but the energy spent on the construction of the building is not addressed. Compared to the entire life cycle of a building, this energy makes up a small share, but even at this stage of construction, savings can be found. Given the current rapid rise in energy prices, any energy savings are noticeable. The subject of the article is the issue of the negative impact of non-compliance with the schedule of work progress or its sub-optimal proposal to increase the amount of energy expended during construction. The aim of the research is to quantify the consumption of individual types of energy input during construction and to determine the specific consumption for the purposes of subsequent comparison and evaluation. An analysis of energy expenditures, determination of critical activities requiring a significant amount of energy and a comparison of five cases of apartment building construction are performed.
\end{abstract}

Key words

Work schedule, energy consumption, winter measure, heating

\section{1 ÚVOD}

Životní cyklus stavby je od počátku do konce spojen se spotřebou energie. Jedná se o energii spotřebovanou pro zhotovení stavby, její provoz, rekonstrukci stavby a energie vydaná při její likvidaci. Současná legislativa se zaměřuje zejména na energii zajišt’ující provoz dokončené stavby. V souladu se zákonem č. 406/2000 Sb. o hospodaření energií a souvisejícími předpisy, zejména vyhláška 264/2020 Sb. o energetické náročnosti budov, předepisují požadavky na tepelně technické vlastnosti konstrukcí a systém technických zařízení budov tak, aby při užívání stavby bylo spotřebováno co nejméně energie, současně zdroj energie by měl pocházet přednostně z obnovitelných zdrojů.

Není však řešena energie vynaložená při výstavbě objektu. V porovnání s celým životním cyklem stavby tato energie tvoří malý podíl, ale i v této etapě výstavby lze shledat úspory. S ohledem na aktuální rychlý růst cen energií je každá úspora energie znatelná.

Cílem výzkumu je kvantifikace spotřeby jednotlivých druhů vložené energie při výstavbě a stanovení měrné spotřeby pro účely následného porovnání a zhodnocení. Je provedena analýza energetických výdejů, stanovení kritických činností vyžadujících významné množství energie a komparace pěti př́padů výstavby bytových domů. 


\section{POPIS SOUČASNÉHO STAVU}

Při studiu dostupné literatury bylo zjištěno, že téma snižování energie při výstavbě není výrazně zohledňováno a nejsou $\mathrm{k}$ dispozici podklady $\mathrm{k}$ jeho studiu. Tuto problematiku mohou řešit stavební firmy pouze interně, $\mathrm{v}$ rámci vlastních zkušeností a dat, vyhodnocením realizovaných zakázek a propočtů. $V$ príípadě větších firem zastávám názor, že $\mathrm{v}$ rámci usilování o získání velké zakázky nejsou tyto okolnosti vůbec uvažovány. Obchodní a marketingové cíle odsouvají zohlednění těchto energií na okraj zájmu.

Vynaloženou energii lze přitom výrazně ovlivnit již ve fázi projektové př́pravy. Sestavením vhodného harmonogramu a jeho dodržováním je možné zbytečně nenavyšovat již tak vysoké energetické nároky. Nedodržení dohodnutého časového plánu prací nejenže může způsobit navýšení nákladů formou sankcí plynoucích z platné smlouvy o dílo, ale může přinést nutnost provedení doplňkových energeticky a finančně náročných opatření, například zimní opatření v případě, kdy pro navazující pracovní činnosti nejsou vhodné okrajové podmínky pro provádění, nebo odvlhčování za účelem zkrácení technologické přestávky.

Do procesu plánování vstupuje mnoho faktorů, je vhodné většinu z nich vzít $\mathrm{v}$ úvahu a vytvořit rozumný kompromis pro optimální stavební postup.

\section{METODIKA}

V průběhu studia byl proveden sběr dat $\mathrm{z}$ realizace větších stavebních objektů, na základě kterého byly stanoveny rozhodující faktory ovlivňující vloženou energii při výstavbě. Po skončení každé stavby byla provedena vlastní rozvaha a zhodnocení, jaká energie byla zbytná, a dalo se předejít jejímu vynaložení.

Do porovnání, které je předmětem tohoto článku, byly zařazeny realizace staveb bytových domů v letech 2010 až 2015, kterých jsem se osobně zúčastnila a vyhodnotila faktory, které ovlivnily celkové náklady na realizaci díla a množství vynaložené energie. Svou konstrukcí a postupem prací byly stavby obdobné. Suterén objektu je proveden jako železobetonová monolitická konstrukce systému bílá vana, konstrukce nadzemních podlaží je tvořena kombinací monolitických železobetonových konstrukcí a zdiva z keramických tvarovek, objekty jsou zatepleny kontaktním zateplovacím systémem. Objekty jsou pěti až sedmipodlažní, suterén objektu slouží jako podzemní garáže a zázemí objektu, v nadzemních podlažích jsou umístěny byty velikostních kategorií $1+$ kk až $4+\mathrm{kk}$.

Pro účely porovnání bylo stanoveno šest hlavních druhů energie, které stavba vyžaduje v různých fázích výstavby. Po celou dobu výstavby je nutno zajistit provoz zařízení staveniště, ve většině případů se jedná o sestavení z obytných kontejnerů vytápěných elektrickými prímotopy. Po dobu realizace monolitických konstrukcí jsou na stavbách využívány stacionární věžové jeřáby, v dalších etapách stavby další stroje a zařízení využívající elektrickou energii.

Zimní opatření při realizaci nosných konstrukcí je nejčastěji provedeno nasazením teplovzdušných agregátů a vytápěním prostoru kolem realizované konstrukce. Při použití paliva extra lehkého topného oleje pro vytápění lze v souladu se zákonem č. 353/2003 Sb. uplatnit nárok na vrácení podstatné části spotřební daně. V porovnání je použita cena po odpočtu vrácené daně.

Pokud to situace na stavbě vyžaduje, je vynaložena snaha o co nejdřívější zprovoznění systému ústředního vytápění a objekt je pak vytápěn otopnými tělesy. Ty je nutno po dobu stavby chránit, aby nedošlo $\mathrm{k}$ jejich poškození.

K odvlhčování je přistupováno v př́ípadě, kdy nejsou již vhodné podmínky k odstraňování zabudované vlhkosti z konstrukcí po dokončení omítek a litých podlah a je nutné zkrátit technologickou přestávku před prováděním následných dokončovacích prací.

$\mathrm{V}$ př́ipadě technologické nekázně a následné nedostatečné kontroly se může ještě v průběhu stavby vyskytnout havárie, kterou je nutno odstranit. Podobné problémy se objevují i později, jsou uplatňovány v rámci reklamace, ty už však nemohou být předmětem porovnání.

\section{Hodnocené náklady a energie}

- Elektrická energie - hlavní podíl tvoří spotřeba energie pro zařízení staveniště, zejména vytápění kancelářských prostor a šaten v zimních měsících, dále spotřeba energie pro provoz strojů (zejména jeřáb, omítačky, stavební výtah, ostatní elektrické nářadí), v př́ípadě použití odvlhčovačů jsou náklady na elektrickou energii součástí položky odvlhčování.

- Zimní opatření - náklady na spotřebu energie ve fázi realizace nosné konstrukce stavby (monolitické železobetonové a zděné konstrukce), náklady na zapůjčení naftových agregátů, palivo extra lehký topný olej po odpočtu spotřební daně, mzdové náklady na manipulaci se zařízeními. 
- Teplo (dokončovací práce) - spotřeba tepla dodávaného otopným systémem ve fázi dokončovacích prací, jedná se o zprovoznění otopného systému a použití otopných těles, v prrípadě neprripravenosti pro zahájení této formy vytápění jsou použity teplovzdušné agregáty, je nutné počítat $\mathrm{s}$ náklady na nájem př́istrojů, spotřebu paliva (extra lehký topný olej, nafta) a mzdové náklady na manipulaci s př́istroji.

- Teplo (před předáním) - spotřeba tepla ve fázi, kdy je objekt dokončený, probíhá předávání bytů klientům a odstraňování vad a nedodělků, v této etapě již neprobíhají stavební práce, ale objekt stále není předán objednateli a efektivně využíván, náklady na energie jdou na vrub zhotovitele.

- Odvlhčování - z důvodu zkrácení technologické přestávky před provedením dokončovacích prací (zejména pokládkou povlakových podlah) se přistupuje $\mathrm{k}$ nasazení odvlhčovačů, v položce je obsaženo nájemné, spotřeba elektrické energie a náklady na manipulaci s prř́stroji (přesun a vylévání nádob s kondenzátem).

- Havárie - náklady a výdej energie na sanaci škod vzniklých v průběhu stavby vadným provedením části konstrukce, jednalo se např́íklad o vysoušení zabudované vlhkosti ve střeše (při provádění střechy při nevhodných vnějších podmínkách), prasklé potrubí ústředního vytápění a zatečení vody do konstrukce podlahy.

\section{Stručný popis hodnocených staveb}

- Rezidence Tupolevova, Praha- Letňany (06 / 2010 - 11 / 2011, cena díla 96,4 mil. Kč) (Obr. 1),

- prodlení se zahájením díla tři měsíce z důvodu čekání na získání stavebního povolení, nosná konstrukce objektu realizována v zimních měsících- nutná zimní opatření, před dokončením zjištěna havárie v bytě- prasklé potrubí otopného systému v podlaze, nutné odvlhčování, předávání bytů klientům a odstraňování vad a nedodělků v podzimních měsících, náklady na vytápění do konce roku byly hrazeny zhotovitelem.

- Nové Měcholupy II, Praha- Horní Měcholupy (01 / 2012 - 03 / 2013, cena díla 124,4 mil. Kč) (Obr. 2),

- prodlení při realizaci nosné konstrukce objektu, omítky a lité podlahy dokončeny v listopadu- špatné podmínky pro snížení zabudované vlhkosti, nutné nasazení odvlhčovačů, v době nedokončeného otopného systému použity $\mathrm{k}$ vytápění teplovzdušné agregáty, následovalo vytápění systémem ústředního vytápění, vytápění po celé zimní období (ve fázi dokončovacích prací a před předáním díla investorovi).

- Nové Měcholupy III, Praha- Horní Měcholupy (11 / 2012 - 03 / 2014, cena díla 90,0 mil. Kč) (Obr. 3),

- navazující etapa na Měcholupy II, zkušenosti z předchozí etapy, vyřešeny detaily, vzorkovánídodržení navrženého harmonogramu, nebyla nutná zimní opatření a odvlhčování, vyskytla se havárie v bytě- nutné lokální odvlhčování, v období dokončovacích prací zprovozněn otopný systém, vytápění pokračovalo v době předání díla a odstraňování vad a nedodělků.

- Obytný soubor Čakovický park, Praha- Čakovice (04 / 2011 - 01 / 2015, cena díla 384 mil. Kč),

- Soubor šesti bytových domů ve třech etapách, nutná zimní opatření při realizaci nosné konstrukce objektu, prováděno odvlhčování, prováděno vytápění otopnými tělesy v období dokončování bytů a jejich předávání.

- Trio rezidence, Praha- Zličín (03 / 2014 - 12 / 2015, cena díla 115 mil. Kč) (Obr. 4),

- dokončení monolitických a zděných konstrukcí v měsících listopadu a prosinci, v zimních měsících osazeny výplně otvorů, realizace prací uvnitř objektu s lokálním vytápěním, vytápění objektu pomocí ústředního vytápění $\mathrm{v}$ období dokončovacích prací a v průběhu přejímek a odstraňování vad a nedodělků.

Hlavní stavební etapy, které ovlivní množství vložené energie, jsou zobrazeny ve zjednodušeném grafickém zobrazení harmonogramu postupu prací. U stavebních prací se jedná o činnosti s velkým množstvím vázané vody, kdy je nutno dodržet minimální teplotu pro provádění a udržování požadované teploty po určenou dobu zrání. V prŕípadě, že tyto činnosti spadají do zimního období, je nutné provádět nákladná dodatečná opatření.

Prodloužení doby předávání bytů a odstraňování vad a nedodělků způsobuje to, že náklady na provoz objektu jdou k tíži generálního dodavatele, naopak snahou objednatele bývá co nejvíce oddálit termín převzetí objektu do vlastní správy. V př́padě nekvalitně provedeného díla a velkého množství vad trvá toto přechodné období několik měsíců a navýšení nákladů na energie tvoří další významnou položku. Při havárií se vždy jedná o energetický výdej, který je možno eliminovat. 


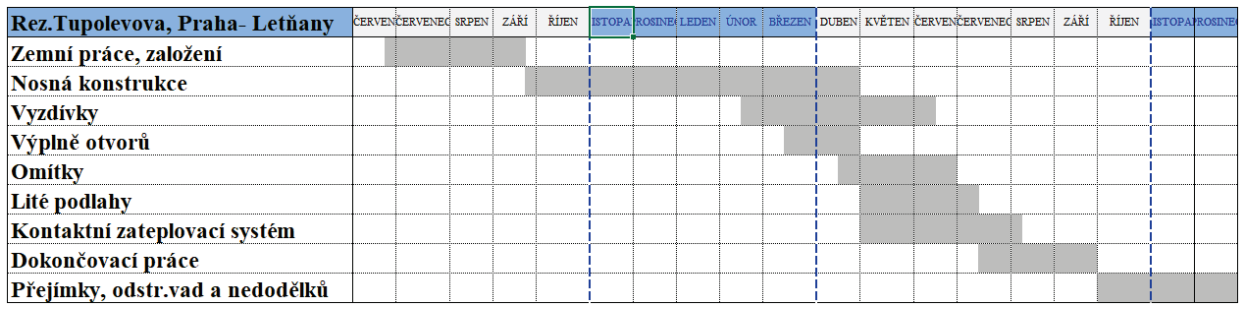

Obr. 1 Rezidence Tupolevova, Praha (Letňany)- Skutečný časový postup prací hlavních etap výstavby ovlivňujících vloženou energii.

\begin{tabular}{|c|c|c|c|c|c|c|c|c|c|c|c|c|c|c|}
\hline Nové Měcholupy II- objekty A, B & LEDEN & ÚNOR & BŔEZEN & DUBEN & KVĚTEN & ČERVEN & ČERVENEC & SRPEN & ZÁR̆́i & Ř́JN & ISTOPALPROSINEC & LEDEN & ÚNOR & BŘEZEN \\
\hline Zemní práce, založení & & & & & & & & & & & & & & \\
\hline Nosná konstrukce & & & & & & & & & & & & & & \\
\hline Vyzdívky & & & & & & & & & & & & & & \\
\hline Výplně otvorů & & & & & & & & & & & & & & \\
\hline Omitky & & & & & & & & & & & & & & \\
\hline Lité podlahy & & & & & & & & & & & & & & \\
\hline Kontaktní zateplovací systém & & & & & & & & & & & & & & \\
\hline Dokončovací práce & & & & & & & & & & & & & & \\
\hline Přejímky, odstr.vad a nedodělků & & & & & & & & & & & & & & \\
\hline
\end{tabular}

Obr. 2 Nové Měcholupy II, Praha (Horní Měcholupy)- Skutečný časový postup prací hlavních etap ovlivňujících vloženou energii.

\begin{tabular}{|c|c|c|c|c|c|c|c|c|c|c|c|c|c|c|c|}
\hline Nové Měcholupy II- objekt C & ROSINEC & C LEDEN & UNOR & BŘEZZN & DUBEN & KVĚTEN & ČERVEN & CERVENEC & SPPEN & ZÁŘ́í & Rिi.EN & LISTOPALPROSINEC & C LEDEN & UNOR & BŘEZEN \\
\hline Zemní práce, založení & & & & & & & & & & & & & & & \\
\hline Nosná konstrukce & & & & & & & & & & & & & & & \\
\hline Vyzdívky & & & & & & & & & & & & & & & \\
\hline Výplně otvorù & & & & & & & & & & & & & & & \\
\hline Omítky & & & & & & & & & & & & & & & \\
\hline Lité podlahy & & & & & & & & & & & & & & & \\
\hline Kontaktní zateplovací systém & & & & & & & & & & & & & & & \\
\hline Dokončovací práce & & & & & & & & & & & & & & & \\
\hline Přejímky, odstr.vad a nedodělkủ & & & & & & & & & & & & & & & \\
\hline
\end{tabular}

Obr. 3 Nové Měcholupy III, Praha (Horní Měcholupy)- Skutečný časový postup prací hlavních etap ovlivňujících vloženou energii.

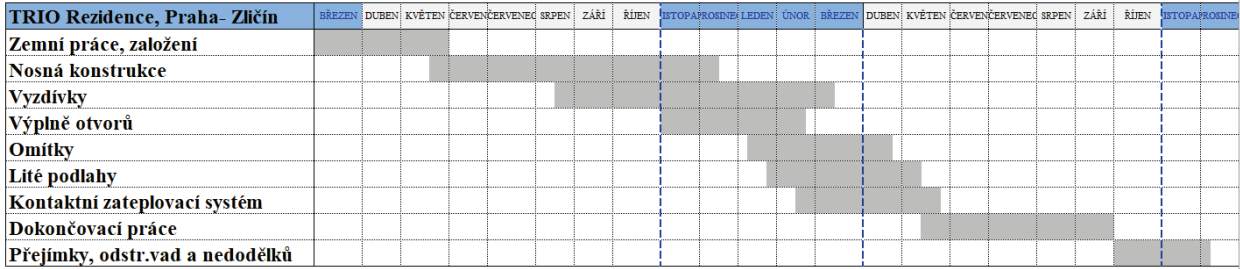

Obr. 4 Trio rezidence, Praha (Zličín)- Skutečný časový postup prací hlavních etap ovlivňujících vloženou energii.

Na zmíněných stavbách nebylo nutno provádět doplňková opatření při realizaci kontaktního zateplovacího systému. V př́ípadě jejich nutnosti by vznikla další významná položka pro porovnání, kdy je nutno obalit lešení termoizolační plachtou a prostor kolem fasády několik dní nepřetržitě vytápět. 


\section{VÝSLEDKY}

Výše uvedené faktory byly kvantifikovány a pro účely porovnání byl vyjádřen poměr skutečných nákladů na energie k celkové smluvní ceně díla viz Tab. 1. Jejich grafické znázornění představuje Obr. 5.

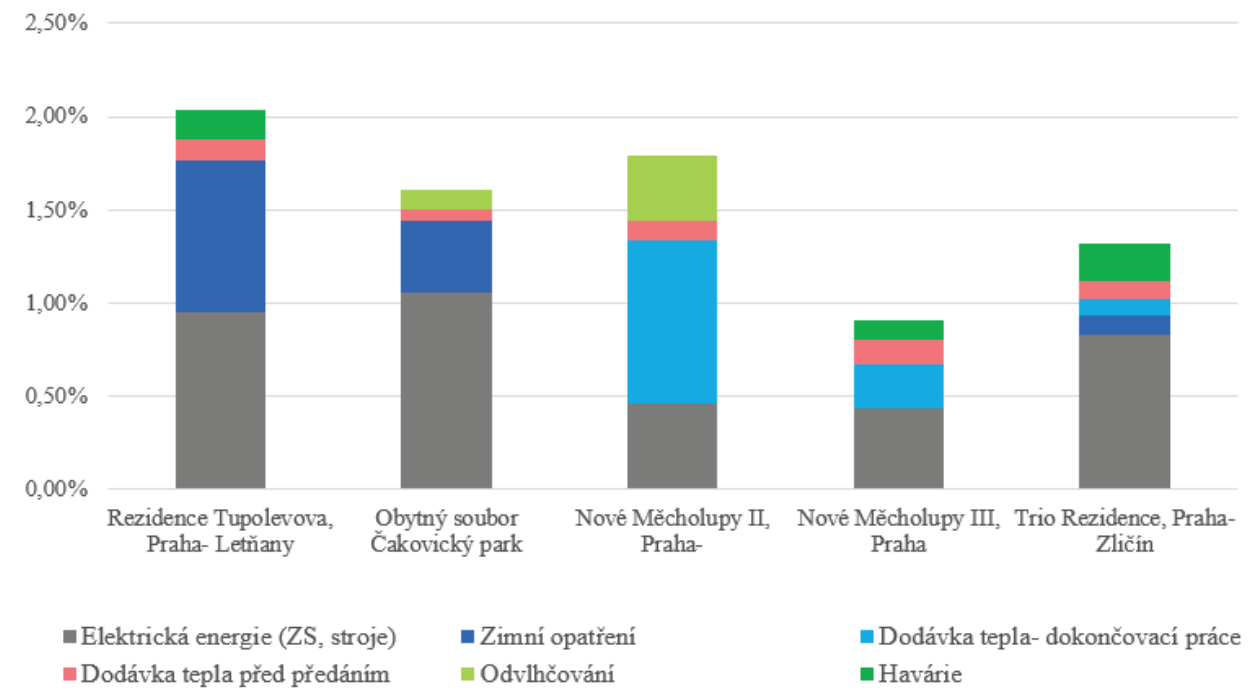

Obr. 5 Grafické znázornění jednotlivých druhů vložené energie v poměru ke smluvní ceně díla.

Tab. 1 Vynaložená energie v průběhu stavby vyjádřená poměrem ke smluvní ceně díla jednotlivých staveb.

\begin{tabular}{ccccccc}
\hline & & $\begin{array}{c}\text { Tupolevov } \\
\text { a }\end{array}$ & $\begin{array}{c}\text { Nové } \\
\text { Měcholupy } \\
\text { II }\end{array}$ & $\begin{array}{c}\text { Nové } \\
\text { Měcholupy } \\
\text { III }\end{array}$ & $\begin{array}{c}\text { Čakovický } \\
\text { park }\end{array}$ & $\begin{array}{c}\text { Trio } \\
\text { rezidence }\end{array}$ \\
\hline Elektrická energie & {$[\%]$} & 0,95 & 0,35 & 0,44 & 1,05 & 0,83 \\
Zimní opatř́ení & {$[\%]$} & 0,82 & 0 & 0 & 0,39 & 0,10 \\
Teplo- dokončovací práce & {$[\%]$} & 0 & 0,88 & 0,23 & 0 & 0,08 \\
Teplo- před předáním & {$[\%]$} & 0,11 & 0,10 & 0,14 & 0,06 & 0,10 \\
Odvlhčování & {$[\%]$} & 0 & 0,46 & 0 & 0,1 & 0 \\
Havárie & {$[\%]$} & 0,16 & 0 & 0,11 & 0 & 0,21 \\
CELKEM & {$[\%]$} & 2,04 & 1,66 & 1,79 & 0,91 & 1,32 \\
\hline
\end{tabular}

Tab. 2 Vynaložená energie v průběhu stavby vyjádřená náklady v přepočtu na obytnou plochu objektu.

\begin{tabular}{ccccccc}
\hline & & $\begin{array}{c}\text { Tupolevo } \\
\text { va }\end{array}$ & $\begin{array}{c}\text { Nové } \\
\text { Měcholup } \\
\mathbf{y ~ I I}\end{array}$ & $\begin{array}{c}\text { Nové } \\
\text { Měcholup } \\
\text { y III }\end{array}$ & $\begin{array}{c}\text { Čakovick } \\
\text { ý park }\end{array}$ & $\begin{array}{c}\text { Trio } \\
\text { rezidence }\end{array}$ \\
\hline Obytná plocha & {$[\mathrm{m} 2]$} & 4749 & 5429 & 4205 & 17689 & 4064 \\
Elektrická energie & {$[\mathrm{Kč} / \mathrm{m} 2]$} & 192,74 & 105,02 & 93,54 & 228,50 & 235,25 \\
Zimní opatřnení & {$[\mathrm{Kč/m} 2]$} & 166,32 & 0 & 0 & 84,42 & 29,15 \\
Teplo- dokončovací práce & {$[\mathrm{Kč} / \mathrm{m} 2]$} & 0 & 201,92 & 49,48 & 11,92 & 23,76 \\
Teplo- před předáním & {$[\mathrm{Kč} / \mathrm{m} 2]$} & 21,60 & 22,91 & 29,29 & 13,52 & 27,25 \\
Odvlhčování & {$[\mathrm{Kč/m} 2]$} & 0 & 80,19 & 0 & 22,41 & 0 \\
Havárie & {$[\mathrm{Kč} / \mathrm{m} 2]$} & 32,91 & 0 & 23,0 & 0 & 58,56 \\
CELKEM & {$[\mathrm{Kč/m} 2]$} & 413,55 & 410,04 & 195,31 & 360,77 & 373,56 \\
\hline
\end{tabular}


Finanční porovnání a přepočet nákladů na jednotku obytné plochy uvedené v Tab. 2 je zatíženo odchylkou způsobenou každoroční inflací, která v letech 2010 až 2015 činila každoročně průměrně 1,7 \% [1]. Tato hodnota je však pro obecnou představu lépe vypovídající než hodnota procentuální.

V př́ípadě procentuálního porovnání tvoří odchylky skutečnost, že každá zakázka je naceněna individuálně, smluvní cena díla je kalkulována s odlišným ziskem. Přesnější je porovnání hodnot spotřebované energie, v tomto př́ipadě by však nebyly zohledněny náklady na nájmy př́strojů a mzdové náklady, které nejsou zanedbatelné.

\section{DISKUZE}

Vzhledem $\mathrm{k}$ individualitě každé stavby a odlišným okrajovým podmínkám je nutno počítat s tím, že výsledná spotřeba energie se může lišit v řádech desítek procent. Porovnání však poskytuje základní představu o kritických obdobích výstavby a hrubém odhadu množství energie, které si vyžádají.

Vypovídající je případ dvou etap výstavby obytného souboru Nové Měcholupy II a III. V první etapě výstavby došlo k prodlení při realizaci nosné konstrukce objektu, které následně způsobilo dokončení omítek a litých podlah v měsíci listopadu v období, kdy již nejsou vhodné podmínky pro přirozený odvod zabudované vlhkosti. $\mathrm{Z}$ důvodu zkrácení technologické přestávky byly prostory bytů vytápěny pomocí naftových agregátů na teplotu $30^{\circ} \mathrm{C}$ spolu s nasazením velkého množství odvlhčovačů. Tento postup zapříčinil výrazné navýšení spotřeby elektrické energie, spotřebu paliva (lehký topný olej), výdaje za nájmy přístrojů a mzdové náklady. Výsledné porovnání dokazuje, že náklady na energie byly v druhé etapě poloviční oproti nákladům v předchozí etapě, přitom se jednalo o téměř identické stavby se stejným plánem postupu prací (v rámci kalendářního roku). Ekonomičnost druhé etapy byla dosažena díky získaným zkušenostem, pokračovala spolupráce s dodavateli z předchozí etapy, byly vyř̌š̌eny konstrukční detaily a zhotovitel měl zkušenosti s realizací a představou objednatele.

\section{ZÁVĚR}

Výše uvedeným porovnáním bylo prokázáno, jak podstatný vliv na spotřebu energie má správná projektová př́iprava a důsledné dodržování harmonogramu postupu prací. Zdržení stavby způsobí nejen riziko vysokých sankcí plynoucích z platné smlouvy o dílo, ale také vysoké náklady na spotřebu energie a nájmy př́ístrojů. Proto je nutné při prvních náznacích o možném zdržení okamžitě jednat a posílit pracovní čety i za cenu zvýšení výdajů. Toto včasné jednání a prvotní vícenáklady mohou být minimální v porovnání s výsledným finančním navýšením.

$\mathrm{Na}$ základě získaných dat si lze udělat představu o nákladech za energie již ve fázi výrobní přípravy. Při usilování o získání stavební zakázky a jednání o smluvních podmínkách je vhodné zohlednit tyto okolnosti a nesnažit se o co největší zkrácení doby výstavby, případně lze přizpůsobit termín zahájení stavby tak, aby pro kritické činnosti byly dosaženy vhodné klimatické podmínky.

Častým problémem bývá i prodlení ze strany objednatele, zahájení stavby je odsouváno z důvodu legislativních (není vydáno rozhodnutí o povolení stavby) či finančních (není bankou schválen úvěr), v průběhu stavby se investor rozhodne pro změnu, vzniká prodlení při vyjednávání, projekčních pracích, vzorkování. Př́ípadně je nutno stavbu neúměrně urychlit z důvodu termínu pro čerpání dotací. I tyto skutečnosti způsobí komplikace a navýšení nákladů za energie při realizaci. Tato skutečnost však nebývá zakotvena ve smlouvě o dílo a ve většině př́ípadů vzniklé nepř́mé vícenáklady nese zhotovitel. Výzkum také může přispět k úvaze, že nejlevnější dodavatel nepřinese vždy úsporu, naopak jeho nespolehlivé konání může způsobit vysoké vícenáklady spojené nejen $\mathrm{s}$ vícenáklady za energie.

\section{Poděkování}

Článek vznikl v rámci řešení juniorského specifického výzkumu č FAST-J-21-7378 „Analýza stavebnětechnologických procesů při realizaci, provozování a údržbě environmentálně šetrného zastřešení budov“.

\section{Použité zdroje}

[1] [online]. [cit. 2021-11-27]. Dostupné z: https://www.czso.cz/csu/czso/mira_inflace

[2] HUDCOVÁ, Lenka. Energetická náročnost budov [online]. Praha: EkoWĀTT, 2009 [cit. 2021-11-27]. ISBN 978-80-87333-03-7. Dostupné z: https://www.mpoefekt.cz/upload/7799f3fd595eeee1fa66875530f33e8a/Brozura_Energeticka_narocnost_budov.pdf

[3] SCHINDLER, Jan. Ceny energií, situace na trhu a doporučení pro zákazníky ke konci roku 2021 [online]. 5.10.2021 [cit. 2021-11-27]. Dostupné z: https://www.tzb-info.cz/ceny-paliv-a-energii/22860-cenyenergii-situace-na-trhu-a-doporuceni-pro-zakazniky-ke-konci-roku-2021 